\title{
Effect of dry period length on reproduction, health and milk production in the subsequent lactation of Holstein cows
}

\author{
M. M. Hussein \\ Department of Theriogenology Faculty of Veterinary Medicine, Beni-Suef University, Beni-Suef \\ 62511, Egypt.
}

\begin{abstract}
A retrospective study was employed to investigate the effect of dry period length on reproduction, incidence of reproductive and metabolic disorders and milk production in Holstein cows belonging to a commercial dairy. Over a 5 year period (2000- 2005), data about reproductive performance, postpartum and metabolic disorders were collected on 1914 multiparous Holstein cows. Out of the obtained data production performance were available only for 793 cows. According to the obtained data the dry period was categorized into 10 groups of different lengths. Reproductive performances including the interval to 1st service, service period, number of inseminations per conception, day's open, calving interval and percentage of pregnant cows within 100 days in milking (DIM) were recorded as a function of dry period length. The incidence of postpartum reproductive and metabolic disorders included retained fetal membranes (RFM), endometritis, cystic ovarian disease (COD), mastitis, milk fever (MF), ketosis and abomasal displacement were recorded as a function of dry period length. Milk production was also studied in relation to dry period length. Statistical analysis of the obtained data was performed.

The most important notifiable results were: cows with dry period less than 28 days showed the best reproductive performance and the highest incidence of abomasal displacement among all groups. In general, the incidence of MF and RFM were higher in short dry period cows, while the incidence of ketosis was higher in cows with long dry period length. A highly significant difference was recorded between daily milk yield of cows with dry period less than 64 days $(27.23 \mathrm{~kg})$ and those of cows with dry period $>64$ days $(25.20 \mathrm{~kg})$.

Finally, it is recommended to keep the dry period of 40-60 day lengths to obtain optimum reproduction, health and production of Holstein cows.
\end{abstract}

The last 4 to 5 years have seen a renewed interest in the effects of dry period length on the performance of dairy cattle. Although this topic has received considerable attention in the past (Schaeffer and Henderson, 1972; Coppock et al., 1974; Dias and Allaire, 1982 and Funk et al., 1987), dairy cattle populations have changed substantially, both genetically and phenotypically over the last 20 years. Selection has brought substantial genetic changes in all breeds, and management practices have evolved considerably as well (AIPL, 2006). Thus, recent research (Bachman, 2002; Gulay et al., 2003; Kuhn et al., 2005; Rastani et al., 2005) has explored length of dry period effects for modernday dairy cattle in modern management systems.

It is well established that a dry period is required to replace senescent mammary epithelial cells and increase the epithelial

\footnotetext{
* Corresponding author. Tel.: +20 2322066;

Fax: +20 822327982.

E-mail address: affash@bsu.edu.eg

Mahmoud Mohammed Hussein
}

component of the gland before the next lactation (Capuco et al., 2003; Annen et al., 2007). Historical studies have shown that an optimal dry period length (DPL) is between 50 and $60 \mathrm{~d}$ (Funk et al., 1987; Sorensen and Enevoldsen 1991; Makuza and McDaniel; 1996). However, recent studies in the United States have supported the use of shorter dry periods with minimal effects on subsequent milk yields (Gulay et al., 2003; Annen et al., 2004; Rastani et al., 2005). More recently, it has been documented that short dry periods can be applied successfully for multiparous cows rather than primiparous cows (Pezeshki et al., 2007). Apparently, primiparous cows are more sensitive to reduced DPL and, consequently, they do not produce much milk as multiparous (Pezeshki et al., 2007). Some studies reported that long dry periods (70 days) have negative effects on milk production in the next lactation (Schaeffer and Henderson 1972; Sorensen and Enevoldsen 1991). Omitting the dry period reduces milk yield with about $11-25 \%$ in the next lactation 
(Remond et al., 1992; Rastani et al., 2005), unless somatotropin is used (Annen et al., 2004). Information relating the effects of dry period length to subsequent reproductive performance and health disorders of lactating cows is sparse. Lotan and Adler (1976) reported that, days open, number of inseminations per conception, and pregnancy rates for 18 pairs of dairy cows having DP of 30 and $60 \mathrm{~d}$ were numerically similar. However, the number of animals for each group was a limiting factor for statistical analysis in that study (n9). Furthermore, other studies reported the binomial reproductive measurements cows submitted to the same short dry periods (Gulay et al., 2003; Annen et al., 2004), within sufficient statistical power (Annen et al., 2004;Gümen et al., 2005). Recently, Watters et al., (2006) demonstrated fewer days open and greater pregnancy rate in cows with shorter dry periods. Moreover, Pezeshki et al., (2008) reported that, a 28- d dry period had no negative effect on health status and reproductive efficiency of the multiparous dairy cows compared with a standard dry period (49d). A previous report (Enevoldsen and Sorensen 1992) was unable to demonstrate any effect of shortening the DPL on some typical metabolic disorders. More recently Watters et al., (2008a) reported that, the length of dry period had no effect on the incidences of ketosis, retained placenta, displaced abomasum, and metritis.

Because of the conflicting reports of the previous studies, the objectives of the current study were to evaluate the effects of dry period length on the reproductive performance, incidence of postpartum health disorders and production of multiparous Holstein cows in a commercial dairy farm under the Egyptian circumstances.

\section{Materials and methods}

Animals. Reproductive, productive and health data of 1914 multiparous Holstein cows on a large commercial dairy farm were recorded. The farm was located in Al Nobaria Region, El Behera Governorate - Egypt. The farm maintained strict TB and brucellosis control measures. Calving occurred throughout the year, with a slightly higher number of animals planned to calve towards the hot season when demand for milk was higher.

\section{Management}

Housing and nutrition. The animals were housed in an open yard system and were allocated according stage of lactation and daily milk production. All cows were milked 3 times each day except during the first 30 DIM when they were milked 4 times daily. All cows were fed on TMR according NRC (1989 and 2001) and had free access to water.

Dry off protocol. The day of dry off was defined according to the stage of lactation, daily milk yield or the incidence of long standing subclinical mastitis. Cows were dried off over a 24-h period that involved two milking. Cows were milked once and then returned to a pen with no access to water. The diet was altered by adding straw and was lower in energy than the diet fed to lactating cows. Twenty-four hours after the first milking, cows returned to the parlor for a final milking and dry cow treatment. The dry treatment was an intramammary antibiotic designed for dry cows. Early dry cows were fed on the far - off ration with low energy. Two to three weeks before parturition these cows were fed on close - up ration with high energy content. At calving, all cows were moved to a post fresh pen and fed a post fresh lactation diet. The post fresh diet was fed until 30 DIM when a lactation diet was fed for the remainder of the lactation period. As for the length of short or long dry period it was not planned. Cows with short DP were not intended to have a short DP (e.g., cows with twins, cows that spontaneously aborted, cows with incorrect breeding dates). Consequently, these cows were not managed for a short DP. Meanwhile cows with a long dry period were those of long day's open and low milk production.

Reproductive Management. After the voluntary waiting period $(50-60$ days postpartum) all lactating cows were observed for estrus three times per day and the estrus cows were inseminated by using imported world wide frozen semen .The anestrous cows were treated by $\mathrm{PGF}_{2 \dot{\alpha}}$ or a timed AI protocol (Ov-synch program) . Pregnancy diagnosis was performed by rectal palpation between 35 and 50 day after $\mathrm{AI}$, and pregnant cows had their pregnancy reconfirmed immediately at 160 to 180 day pregnant. Cows not diagnosed as pregnant during the rectal exam were enrolled in a timed AI protocol for re-insemination.

Data source. All information about an animal was recorded on an individual sheet on a computer set. Provided individual data included birth date, calving, health and metabolic disorders, inseminations, dry off dates and milk yield results. The last insemination before the subsequent calving was assumed to be the conception date. The interval from $1^{\text {st }}$ 
insemination to the fertile one was considered as a service period. Reproductive performance for individual cow included time to first insemination (TFS), service period (SP), number of inseminations per conception $(\mathrm{S} / \mathrm{C})$, days open (DO) and calving interval (CI). Parameters of services per conception, day's open and calving interval were calculated only for pregnant cows. Health disorders including reproductive and metabolic disorders. Reproductive disorders included retained fetal membranes, endometritis, cystic ovarian disease and mastitis. While the metabolic disorders included milk fever, ketosis and abomasal displacement. Parameters for lactation performance included total lactation yield (MY), 305 day milk yield and average daily milk yield (ADMY). Data of non pregnant cows were excluded.

Monitoring Health Events in Postpartum Cows. Disorders and diseases were defined and determined by the management of the farm according to Merck Veterinary Manual (1998). Retained placenta was defined as the visible presence of fetal membranes at the vulva or identified in the uterus by vaginal examination more than $24 \mathrm{~h}$ after parturition. Endometritis was defined as inflammation of the lining of the uterus as identified by vaginal examination and/or the presence of abnormal cervical or vaginal discharge. Cystic ovarian disease without nymphomaniac behavior was diagnosed by rectal examination. Mastitis was defined as visually abnormal milk secretions such as clots, flakes, or watery consistency from one or more quarters. Inflammation of a quarter was also used to diagnose mastitis. Milk fever was diagnosed by difficulties in standing, staggering and in typical cases the cow's head is in a so-called selfauscultation position with low rectal temperature. Cows were considered to be ketotic if milk production was less than $10 \mathrm{~kg}$ at the morning milking during the first 30 days in milking (DIM). Decreased appetite, manure consistency, and milk yield were also used in the diagnosis of ketosis. KetoCheck powder (Great States Animal Health, St. Joseph, MO), which detects acetoacetate in milk. Displaced abomasum was diagnosed as decreased appetite accompanied by an audible, high pitched tympanic resonance of the left abdominal wall. Mastitis was diagnosed by the milkers, whereas all other disorders were diagnosed by the Veterinarian.

Data set from lactations after the dry period. Records of dry period length were merged with information related to the subsequent lactation. Only records that fulfilled the following requirements were retained: lactation ended with the subsequent dry off day at the end of lactation and cow of complete reproductive data and subsequent calving date recorded. With this edit, only 793 lactations of complete milk yield data were included.

Statistical analysis. A total of 1914 multiparous cows were included in the data analyses. Dry period length were assigned to ten categories $(<$ $28,28-<44,44-<50,50-<56,57-<64,64$ $-<71,71-<85,86-<100,100-<120$ and $>$ 120 days). Only cows that had been diagnosed as pregnant during the subsequent lactation were included in the analysis of reproductive performance and lactation performance was analyzed only for cows of 305 day milk yield with the SAS (1996) program. The incidence of reproductive and metabolic disorders was calculated by regarding any affected cows with one or more disorders as positive $(100 \%)$ and the non affected cow as negative $(00 \%)$. The incidence was statistically calculated as overall mean \pm SEM for each age group according to Thirkettle (1985).

\section{Results}

As shown in (Table 1 and Fig. 1) about seventy percent of dry period was found to be ranged between $44-71$ days. Only $7.63 \%$ of dry period were shorter than 44 days while more than $22 \%$ of those were longer than 71 days.

In general, cows with dry period ( $>71$ days) showed a longer interval to $1^{\text {st }}$ service than those of dry period less than 70 days (table 3). Meanwhile, cows with dry period less than 28 days showed the best reproductive performance among all groups. Service periods were fluctuating with its lower values in cows with dry period $\geq 121$ and $<28$ days and higher values in cows with 64-71 days dry period.

Short dry period $(<28)$ was associated with short days open, low $\mathrm{S} / \mathrm{C}$, short calving interval and high percentage of pregnant cows within 100 DIM. Generally, all reproductive performance were fluctuating without clear trend associating dry period length (Table,1).

The incidence of chronic endometritis was fluctuating without special trend associating the dry period length (Table,2). Retained fetal membranes were higher in cows with short dry period whereas, about $57 \%$ of the incidence occurred in cows with dry period $<56$ days.

The incidence of cystic ovarian disease was fluctuating with peak level in cows around 66 



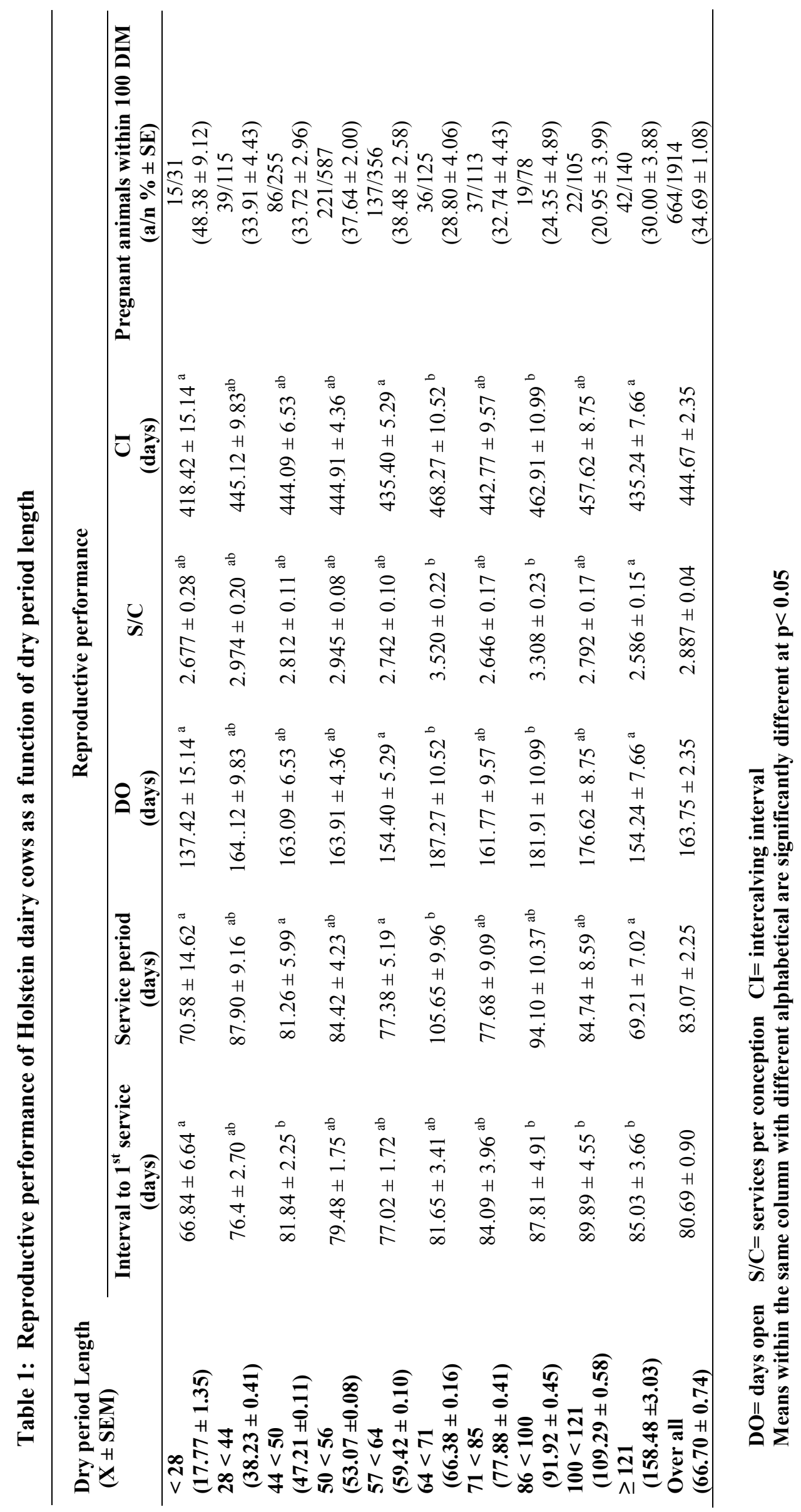




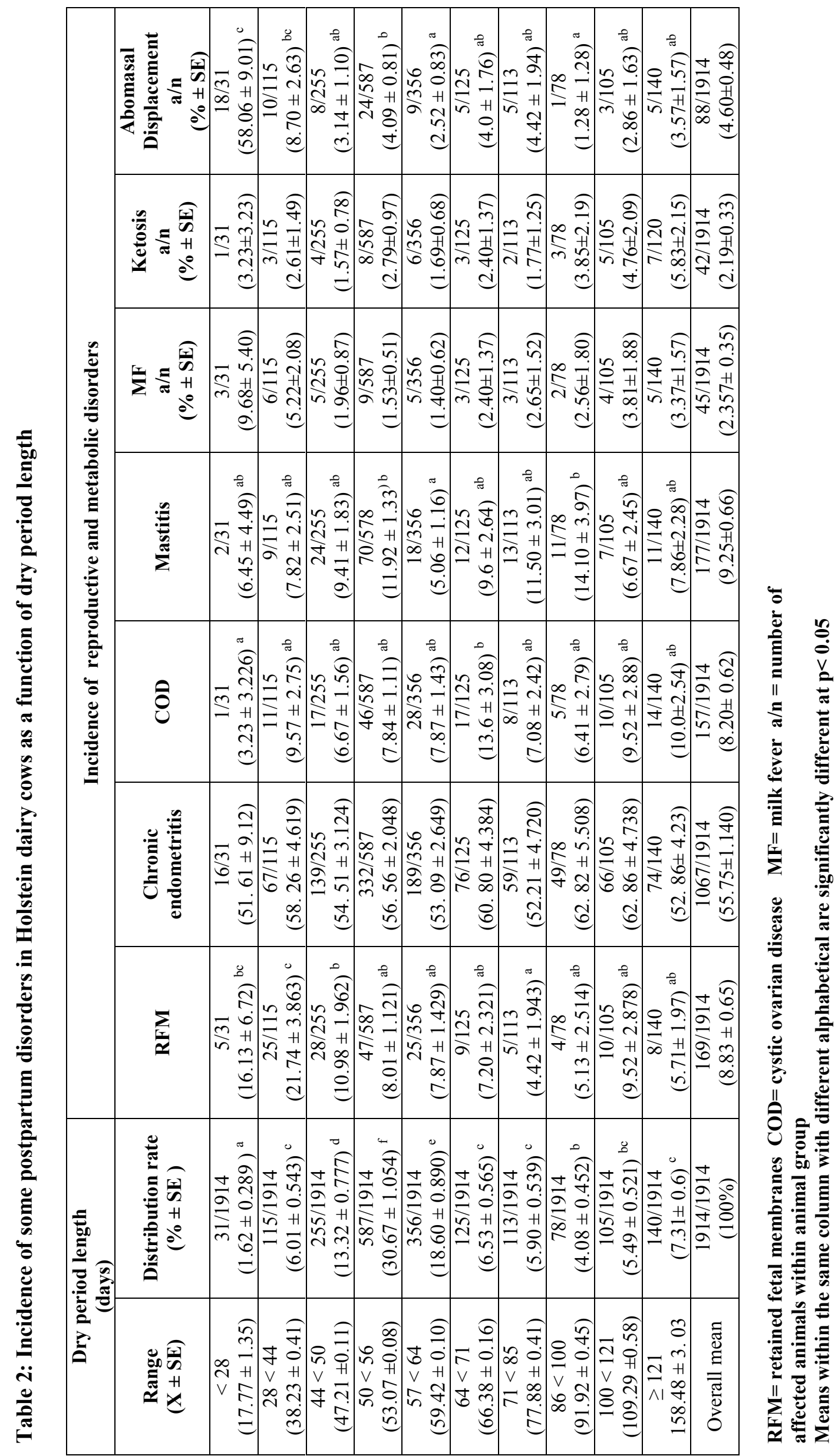


Table 3: Some productive indices in relation to different durations of dry period in Holstein cows

\begin{tabular}{|c|c|c|c|c|}
\hline \multirow{2}{*}{$\begin{array}{l}\text { Dry period length } \\
(\mathrm{X} \pm \mathrm{SEM})\end{array}$} & \multicolumn{4}{|c|}{ Productive performance } \\
\hline & $\mathbf{N}$ & Total MY/ lactation & 305 day MY & ADMY \\
\hline $\begin{array}{l}<28 \\
(17.14 \pm 2.27)\end{array}$ & 14 & $9850.43 \pm 562.63^{b}$ & $7404.08 \pm 392.53^{a b}$ & $24.28 \pm 1.29^{\mathrm{a}}$ \\
\hline $\begin{array}{l}28<44 \\
(38.52 \pm 0.50)\end{array}$ & 62 & $9152.86 \pm 377.40^{\mathrm{ab}}$ & $9004.51 \pm 350.50^{\mathrm{c}}$ & $29.52 \pm 1.15^{c}$ \\
\hline $\begin{array}{l}44<50 \\
(47.29 \pm 0.16)\end{array}$ & 94 & $9262.79 \pm 324.24^{\mathrm{ab}}$ & $8143.93 \pm 234.59^{b}$ & $26.70 \pm 0.77^{b c}$ \\
\hline $\begin{array}{l}50<56 \\
(53.14 \pm 0.12)\end{array}$ & 255 & $9517.13 \pm 179.98^{b}$ & $8366.47 \pm 131.15^{b}$ & $27.43 \pm 0.43^{b c}$ \\
\hline $\begin{array}{l}57<64 \\
(59.52 \pm 0.15)\end{array}$ & 151 & $9365.19 \pm 200.00^{b}$ & $8096.92 \pm 159.61^{b}$ & $26.55 \pm 0.52^{b}$ \\
\hline $\begin{array}{l}64<71 \\
(66.21 \pm 0.21)\end{array}$ & 61 & $8835.39 \pm 369.31^{\mathrm{ab}}$ & $7631.48 \pm 254.87^{\mathrm{ab}}$ & $25.02 \pm 0.84^{\mathrm{a}}$ \\
\hline $\begin{array}{l}71<85 \\
(78.36 \pm 0.63)\end{array}$ & 42 & $9129.43 \pm 422.23^{a b}$ & $7742.92 \pm 271.28^{a b}$ & $25.39 \pm 0.89^{\mathrm{a}}$ \\
\hline $\begin{array}{l}86<100 \\
(93.22 \pm 0.75)\end{array}$ & 36 & $8261.78 \pm 438.36^{\mathrm{a}}$ & $7606.59 \pm 331.09^{a b}$ & $24.94 \pm 1.09^{\mathrm{a}}$ \\
\hline $\begin{array}{l}100<121 \\
(111.33 \pm 1.07)\end{array}$ & 33 & $8976.33 \pm 511.24^{\mathrm{ab}}$ & $8376.40 \pm 488.42^{a b}$ & $27.46 \pm 1.60^{b c}$ \\
\hline $\begin{array}{l}\geq 121 \\
(155.31 \pm 4.60)\end{array}$ & 45 & $8316.84 \pm 386.64^{a}$ & $7259.82 \pm 207.82^{a}$ & $23.80 \pm 0.68^{\mathrm{a}}$ \\
\hline Over all & 793 & $9210.33 \pm 101.03$ & $8142.2 \pm 76.45$ & $26.69 \pm 0.25$ \\
\hline
\end{tabular}

MY= milk yield $\quad$ ADMY $=$ average daily milk yield

Means within the same column with different alphabetical are significantly different at $\mathbf{p}<0.05$.

\section{Distribution of DPL}

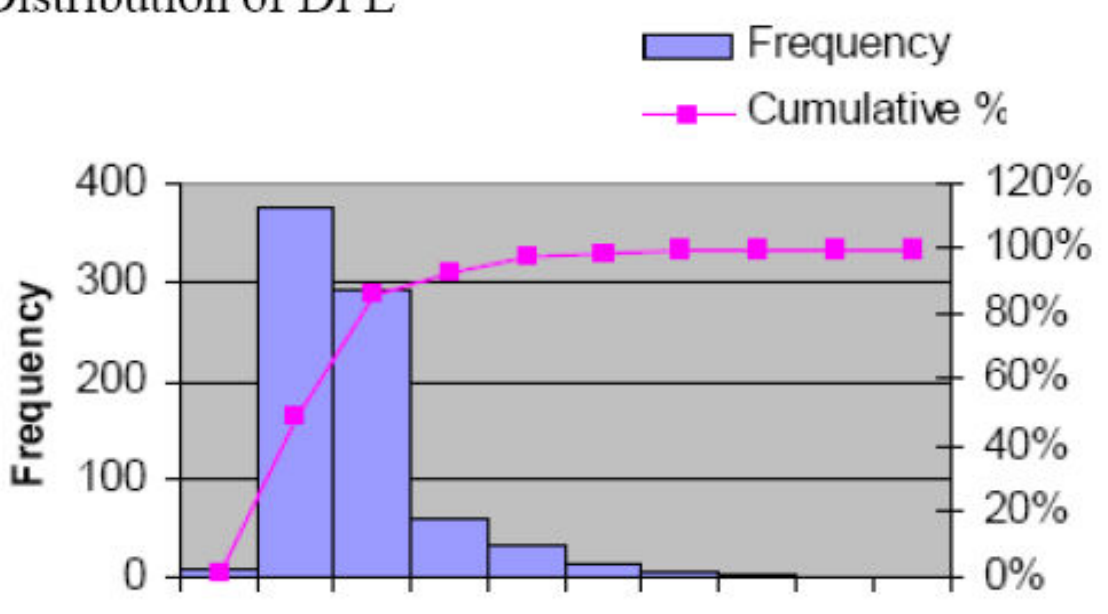

104070100130160190220250280

Fig. 1

DP 

days dry and the bottom level in cows with dry period $<28$ days. Postpartum mastitis was at its peak level in cows with dry period length of 50-56 and 71-100 days. The current study revealed that, cows with short dry period ( $<44$ days) exhibiting a significantly higher percent of abomasal displacement and non significant higher percent of milk fever in comparison with those had longer dry period. Otherwise, cows with long dry periods $(>86$ days) showed a non significant higher incidence of ketosis in comparison with those had shorter dry period ( $<86$ days).

As shown in (Table 3 ) the average daily milk yield and 305 day milk yield were at the peak in cows with previous 28-44 days dry and the bottom in cows with dry period over 121 days. Cows with dry period over 64 days had lower 305 day milk yield in comparison with those had shorter dry periods. A highly significant difference was recorded between daily milk yield of cows with dry period under 64 days $(27.23 \pm$ 0.04 ) and those of cows with dry period over 64 days $(25.20 \pm 0.07 \mathrm{~kg})$. Cows had dry period $<$ 64 days gave total milk yield/ lactation over 9 tons while, those of dry period $>64$ days almost produced total milk yield / lactation less than 9 tons. Cows of short dry period $(<28 \mathrm{~d})$ tend to have longer lactation period in comparison with those of long dry period.

\section{Discussion}

This retrospective study was employed to investigate the effect of dry period length on reproduction, incidence of reproductive and metabolic disorders as well as milk production in a commercial Holstein herd. We hypothesized that reducing the dry period length would result in better reproductive efficiency, as observed in recent studies of Gümen et al., (2005); Grummer et al., (2007).

The present study was conducted on the reproductive and productive data of 1914 cows over a 5 year period (2000-2005) assigned per different dry period lengths. In the current study there was an obvious reduction in the interval to $1^{\text {st }}$ service and days open when cows had a short dry period length $(<28$ days). Nearly the same results were obtained by Gümen et al.,(2005) and Watters et al., (2008b) who reported a reduction in the interval to $1^{\text {st }}$ service and days open by 15 and 24 days, respectively, when cows had a shortened (28 day) vs. a traditional (56 day) dry period.

Furthermore, increased percentage of pregnant cows by 100 DIM was observed in cows having a short dry period. These results agreed with that reported by Gümen et al., (2005). The obtained improvement in reproductive efficiency might be attributed to the axiom that, shorter dry period and earlier ovulation were associated with a reduction in negative energy balance and high dry matter intake (DMI) during the first three weeks after calving (Rastani et al., 2005). Moreover, Grummer, (2007) hypothesized that; fewer days to first ovulation in cows with a shortened dry period would results in earlier pregnancy and consequently reduced the days open. Furthermore, relationships between energy balance (EB) and first postpartum ovulation as well as resumption of ovarian cyclicity were obtained by Butler et al., (1981); Canfield et al., (1990). In the same trend, Rastani et al., (2005) reported that cows received no DP or a reduced DP (28 d) had less negative EB compared with cows received a traditional (56-d) DP. Consistent with the relationship between EB and days to first postpartum ovulation, Gümen et al., (2005) found that cows with shorter DP ovulated sooner (13.2 d, $23.8 \mathrm{~d}$, and $31.9 \mathrm{~d}$ for $0-, 28-$, and 56-d DP, respectively).

It is well known that, reproductive performance of dairy cattle improved with earlier return to ovarian cyclicity (Thatcher and Wilcox, 1973; Staples et al., 1990; Darwash et al., 1997). The results of the present study augment the concept that earlier first ovulation may improve the reproductive performance as it was clear that, decreasing the DP length was associated with a lower interval to 1 st service, decreased days open and increased percentage of pregnant cows within 100 DIM. However, some investigators reported lower (Smith and Wallace, 1998) or no changes (Royal et al., 2000) in reproductive performance with a shorter time to first postpartum ovulation. Furthermore, Lotan and Adler (1976) found that the number of services per conception, pregnancy rate, and days open did not differ when comparing 30- to 60-days dry period. Similarly, Pezeshki et al., (2007) did not find a consistent improvement in reproductive measures with a decreased dry period length, although first-service conception rate was higher in multiparous cows with a 35days dry period compared with a $42-$ or 56 -days dry period.

The results of the present study revealed that, retained fetal membranes were higher in cows with short dry period ( $<44$ days). These results are consistent with that of Grummer and 
Rastani (2005) and come inconsistent with that of Coppock et al., (1974); Davicco et al., (1992). Coppock et al., (1974) indicated that dry period lengths of $20,30,40,50$, and 60 days had no effect on the incidence of ketosis, milk fever, or retained placenta. However, this study was conducted since 35 years ago on what today would be considered low producing cows $(<7,000 \mathrm{~kg} /$ year $)$. The increased incidence of RFM in cows with short dry period might be attributed to the opinion that, stress of high milk yield and hypocalcaemia prevent uterine contractions necessary for expulsion of the placenta, decrease dry matter intake specially in late gestation and early post calving may lead to negative energy balance (NEB). NEB will lead not only to immune suppression but also excessive adipose fatty acid immobilization and consequently increasing the blood levels of non estrified fatty acids (NEFA). Dyk et al., (1995) found that elevated NEFA concentrations during the last $7 \mathrm{~d}$ before calving were associated with greater incidences of ketosis, displaced abomasum, and retained fetal membranes. Moreover, it has been suggested that, the insufficient leukocyte activity immediately postpartum resulting in inadequate collagen breakdown of the tissues and thus a failure of tissue separation (Kimura et al., 2002).

The incidence of cystic ovarian disease in the current study were fluctuating with peak level in cows around 66 days dry and bottom level in cows with dry period $<28$ days. Unfortunately there is no data in the available literature discuss the effect of dry period length on the incidence of cystic ovarian disease.

In the current study, cows with dry period $<$ 28 -d and $>64$ days produced significantly lower daily milk yield than other groups. The results of the current study augment the argument that, the COD are mainly observed in high yielding dairy cows during the first 100 DIM and milk yield is generally considered a risk factor (Hooijer et al., 2001; Lucy, 2001). Moreover, besides the truth that COD are hereditary (Cole et al., 1986), a genetic correlation between cysts and milk production traits was established, indicating that an ongoing selection for production parameters will increase the incidence of COD (Hooijer et al., 2001). Furthermore, these results could be discussed on the base of NEB and its repercussions, as during NEB, circulating concentrations of IGF-1, insulin, glucose (Beam and Butler, 1999) and leptin (Liefers et al., 2003) are reduced, while concentrations of NEFA and $\beta$ - hydroxybutyrate (BHB) are increased (Rukkwamsuk et al., 2000). As mentioned earlier, the IGF system plays an important role in follicle growth and development. Besides a direct effect, IGF-1 together with insulin indirectly stimulates follicular development through up regulation of the LH-receptor on granulosa cells (Davoren et al., 1986). Therefore, low systemic IGF-1 concentrations early post partum could contribute to anovulation and subsequent development of cystic follicles as shown by Zulu et al., (2002). According to the later author, cows developing cysts have high serum NEFA concentrations during the first week(s) post partum. The elevated NEFA concentrations for $48 \mathrm{~h}$ can decrease insulin secretion by the $\beta$-cells of the pancreatic islets in response to a glucose challenge (Mason et al., 1999). Moreover, NEFA are cytotoxic for several cell types, including granulosa cells (Ulloth et al., 2003). Besides NEFA, increased serum ketone concentrations also affect ovarian function (Reist et al., 2000) indicating that these metabolites may be mediators of the negative effect of NEB on follicular development. High ketone concentrations increase the risk of cyst occurrence (Andersson et al., 1991) and consequently are likely candidates to be involved in the occurrence of COD.

The present study revealed that, postpartum mastitis was at its peak level in cows with dry period length of 50-56 and 71-100 days. These results agreed with that of Enevoldsen and Sorensen, (1992); Remond et al., (1992); Gulay et al., (2003); Annen et al., (2004); Rastani et al., (2005); Watters et al., (2008b). Retrospective analysis of data from commercial farms has shown that a dry period of 60 days or less resulted in a higher overall mastitis in the subsequent lactation (Kuhn et al., 2006).

The results of the present study showed a high tendency of short dry period cows to have abomasal displacement. These results agreed with Grummer and Rastani et al., (2005). Abomasal displacement is the most important disease complex associated with the abomasum in cattle commonly occurs in the first 30 days of lactation and is often associated with metabolic or hepatic disease (Rohn et al., 2004). The incidence of left displaced abomasum in dairy cows (LDA) was reported to be $1.2 \%$ and right displaced abomasum (RDA) as $0,4 \%$ (Hamann $e t$ al., 2004). The aetiology of the condition is not clearly established and is probably of a multiple nature, the following risk factors have been 
identified: high yielding cows (Ricken et al., 2004), intensive concentrate feeding, late gestation or early lactation, changes in weather conditions (da Silva et al., 2004), marked body condition score loss in the periparturient period (Kim and Suh, 2003), association with milk fever and poor dry cow management (Ricken et al., 2004).

The current study revealed that, cows with long dry periods ( $>86$ days) showed a non significant higher incidence of ketosis in comparison with those had shorter dry period. Lactating cows are most susceptible to metabolic and infectious diseases during the first few weeks post calving. During this period they are typically in negative energy balance (EB) because they cannot consume sufficient energy to meet requirements for maintenance and lactation (Grummer and Rastani, 2004). Two consequences of negative $\mathrm{EB}$ associated with traditional or long dry period are immune suppression (Burton et al., 2001) and mobilization of fatty acids from adipose tissue (Bertics et al., 1992). Excessive mobilization results in lipid related metabolic disorders, such as hepatic lipidosis and ketosis, and elevated non estrified fatty acids (NEFA) in blood prepartum has been associated with other complications such as retained placenta, mastitis and displaced abomasum (Cameron et al., 1998). There is limited information on the effect of DP length on incidences of health disorders because large animal numbers are required to have sufficient statistical power to detect treatment differences. In agreement with Kuhn and Hutchison, 2005, to assess the effect of shortening the DP on animal health requires the use of a large commercial dairy or several dairies because most of the previous studies were carried on university herds which are typically small and do not facilitate needed replication.

In the current study, cows with dry period less than 28 and more than 64 day produced significantly lower daily milk yield than other groups. Moreover, the estimated 305 DIM yield in the cows with short dry period was $7404.08 \pm$ $392.53 \mathrm{KG}$ which was lower than traditional dry period $(8366.47 \pm 131.15 \mathrm{~kg})$.

Omitting the dry period reduces milk yield with about $11-25 \%$ in the next lactation (Remond et al., 1992; Rastani et al.,2005 and Watters et al., 2008a). Funk et al., (1987) indicated that cows given a DP between 60 and $69 \mathrm{~d}$ produced $459 \mathrm{~kg}$ more milk in the subsequent lactation than those given a DP $<40$ d. Others have reported a loss in milk yield when the DP is reduced to less than $40 \mathrm{~d}$ (Coppock et al., 1974; Remond et al., 1997; Rastani et al., 2005). Sorensen and Enevoldsen (1991) also reported that when the DP was reduced from 10 or $7 \mathrm{wk}$ to $4 \mathrm{wk}$ there was a loss in milk yield by dual-purpose Danish cows. In contrast, Gulay et al., (2003) reported that milk yield did not differ when comparing a 30 - to $60-\mathrm{d}$ DP (38.4 vs. 38.7 $\mathrm{kg} / \mathrm{d}$, respectively). Annen et al., (2004) reported that reducing DP length from 60 to $30 \mathrm{~d}$ significantly affects second-lactation cows but not third and greater lactation cows. A recent retrospective analysis of farm records indicated that milk yields from cows in their third lactation or greater are not affected by DP length whereas those in their second lactation are affected by DP length (Kuhn et al., 2006). The last authors indicated that when days dry are less than 56 , a loss in milk production occurs during the subsequent lactation.

Dias and Allaire (1982) indicated DP length might affect the level of milk production differently depending on length of the calving interval. It was reported that when the calving interval was less than $340 \mathrm{~d}$, a DP of at least $55 \mathrm{~d}$ was required to maximize milk production during two consecutive lactations (Dias and Allaire, 1982).

A highly significant difference was recorded between daily milk yield of cows with dry period under 64 days $(27.23 \pm 0.04)$ and those of cows with dry period over 64 days $(25.20 \pm 0.07 \mathrm{~kg})$. The same results were recorded by Watters et al., (2008a).The last authors reported that, mean postpartum milk production was $2.1 \mathrm{~kg} / \mathrm{d}$ greater for cows with $56 \mathrm{~d}$ compared with $30 \mathrm{~d}$ dry period length. The lower capacity for milk production in the subsequent lactation in the cows of short dry period were not because of differences in days dry or to occurrence of either pre or postpartum calving-related diseases or mastitis, but likely were due to differences in mammary tissue response to local or systemic factors (Gulay et al., 2003; Andersen et al., 2005).

The current study revealed that, cows had dry period $<64$ days gave a total milk yield/ lactation over 9 tons while, those of dry period $>$ 64 days almost produced a total milk yield / lactation less than 9 tons. The same results were reported by Schaeffer and Henderson (1972); Sorensen and Enevoldsen (1991). Cows with long dry period become over conditioned (Wildman et al., 1982). Over conditioned cows, 
when compared with normal cows, have less appetite at calving and high losses in BCS (Gulay et al., 2003), which, in combination with the high energy need for the onset of milk production, results in a greater negative energy balance after calving (Grummer et al., 2000). Body condition score loss was approximately one-quarter point greater after calving in cows given a $60-d$ DP relative to those given a $30-d$ DP; (Gulay et al., 2003).

In the current study, milk production of short dry period cows $(<28 \mathrm{~d})$ pointed to long lactational period versus short dry period which may indicate a high heritability of short dry period and long lactation period.

These observational datasets of the current study were analyzed retrospectively, the number of records for cows with $<28-\mathrm{d}$ dry periods is limited relative to the number of records for cows with traditional dry periods. More importantly, the cows with short dry periods within these datasets were not assigned at random to have a planned short dry period. Instead, the $<28-\mathrm{d}$ dry-period category is composed primarily of a nonrandom population of cows that freshened earlier than expected for various reasons. Moreover, these cows did not manage to best prepare them to transition into a profitable lactating state by monitoring her body condition and providing an appropriate dietary regimen as calving approaches. Thus, results obtained using the retrospective data analysis approach are biased in favor of identifying the 60-d dry period as being more beneficial, in terms of subsequent milk yields, than the $<28$ - $d$ dry period.

\section{Conclusion}

Shortening the DP results in early improvement of fertility but diminished as lactation lengthened. This improvement was probably due to a decrease in postpartum milk production. Shortening the DP without planned feeding during the transitional period would result in improper metabolic status in the subsequent lactation. Therefore, it is recommended to keep the dry period of 40-60 day length to obtain optimum reproduction, production and health of Holstein cows under Egyptian circumstances.

Moreover, it seems clear that further research is needed to define the relationships between fertility, endocrine measures, metabolic measures, and first ovulation, particularly as altered by different dry period lengths.

\section{References}

AIPL Animal Improvement Programs Laboratory (2006):Trend in Milk breeding values for Holstein calculated

August,2006.http://aipl.arsusda.gov/dynamic/trend/current/t r dx.html Accessed Sept.18, 2006.

Andersson, L.; Gustafsson, A. H.; Emanuelson, U. (1991): Effect of hyperketonemia and feeding in dairy cows. Theriogenology 36, 521-535

Andersen, J. B.; Madsen, T. G.; Larsen, T.; Ingvartsen, K. L. and Nielsen, M.O. (2005): The Effects of Dry Period Versus Continuous Lactation on Metabolic Status and Performance in Periparturient Cows. J. Dairy Sci. 88: 35303541.

Annen, E. L.; Collier, R. J.; McGuire, M. A.; Vicini, J. L.; Ballam, L. A., and Lormore, M. J. (2004): Effect of modified dry period lengths and bovine somatotropin on yield and composition of milk from dairy cows. J. Dairy Sci. 87:3746-3761

Annen, E. L.; Fitzgerald, A.C.; Gentry, P.C.; McGuire M. A.; Capuco, A.V.; Baumgard, L. H. and Collier, R. J. (2007): Effect of continuous milking and bST supplementation on mammary epithelial cell turnover. J. Dairy Sci. 90: 165-183.

Bachman, K. C.(2002): Milk production of dairy cows treated with estrogen at the onset of a short dry period. J.Dairy Sci. 85: 797-803

Beam, S. W. and Butler, W. R. (1999): Effects of energy balance on follicular development and first ovulation in postpartum dairy cows. J Reprod Fertil, Supplement 54: 411-424.

Bertics, S. J.; Grummer, R. R.; Cadorniga-Valino, C.; LaCount, D. W. and Stoddard, E. E. (1992): Effect of prepartum dry matter intake on liver triglyceride concentration and early postpartum lactation. J. Dairy Sci. 75:1914-1922.

Burton, J. L.; Madsen, S.A.; Yao, J.; Sipkowsky, S. S. and Coussens, P. M. (2001): An immunogenetics approach to understanding immunosuppression and mastitis suseptibility in dairy cows. Acta Vet. Scand. 42:407-424.

Butler, W. R.; Everett, R. W. and Coppock, C. E. (1981): The relationships between energy balance, milk production and ovulation in postpartum Holstein cows. J. Anim. Sci. 53:742-748.

Cameron, R. E.; Dyke, P. B.; Herdt, T. H.; Kaneene, J. B.; Miller, R.; Buckholz, H. F.; Liesman, J. S.; Vandehaar, M. J. and Emery, R. S. (1998): Dry cow diet, management, and energy balance as risk factors for displaced abomasum in high producing dairy herds. J. Dairy Sci. 81:132-139.

Canfield, R. W.; Sniffen, C. J. and Butler, W. R. (1990): Effects of excess degradable protein on postpartum reproduction and energy balance in dairy cattle. J. Dairy Sci. 73:2342-2349.

Capuco, A.V.; Ellis, S. E.; Hale, S. A.; Long, E.; Erdman, R. A.; Zhao, X. and Paape, M. J. (2003): Lactation persistency: in sights from mammary cell proliferation studies. J. Dairy. Sci. 81 (Suppl3):1831.

Coppock, C. E.; Everett, R. W.; Natzke, R. P. and Ainslie, H. R. (1974): Effect of Dry Period Length on Holstein Milk Production and Selected Disorders at Parturition. J.Dairy Sci.Vol. 57. (6): 712-718

Cole, W. J.; Bierschwal, C. J.; Youngquist, R. S. and Braun, W. F. (1986): Cystic ovarian disease in a herd of Holstein cows: a hereditary correlation. Theriogenology 25: 813-820 
da Silva, C.; Shauberger, J., G.; Oliveira, R. M.; Segao, S.; Kumper, H. and Baumgartner, W. (2004): Does the weather influence the occurrence of abomasal displacement in dairy cows? Deutsche Tierarztliche Wochenschrift 111:51-57.

Darwash, A. O.; Lamming, G. E. and Woolliams, J. A. (1997): The phenotypic association between the interval to post-partum ovulation and traditional measures of fertility in dairy cattle. Anim. Sci. 65:9-16.

Davicco, M. J.; Remond, B.; Jabet, S. and Barlet, J. P. (1992): Plasma osteocalcin concentrations in cows around parturition. The influence of a regular versus a very short dry period. Reprod. Nutr. Dev. 32:313-319.

Davoren, J. B.; Kasson, B.G.; Li, C.H. and Hsueh, A.J. (1986): Specific insulin-like growth factor (IGF)-I and IIbinding sites on rat granulosa cells: relation to IGF action. Endocrinology 119: 2155-2162.

Dias, F. M.; and Allaire, F. R. (1982): Dry period to maximize milk production over two consecutive lactations. J.Dairy Sci. 65:136-145.

Dyk, P. B.; Emery, R. S.; Liesman, J. L.; Bucholtz, H. F. and VandeHaar, M. J. (1995). Prepartum non-esterified fatty acids in plasma are higher in cows developing periparturient health problems. J. Dairy Sci. 78(Suppl. 1):264. (Abstr.)

Enevoldsen, C., and Sorensen, J. T. (1992): Effects of dry period length on clinical mastitis and other major clinical health disorders. J. Dairy Sci.75:1007-1014.

Funk, D. A.; Freeman, A. E. and Berger, P. J. (1987): Effects of pervious Days open, previous days dry, and present days open on lactation yield. J. Dairy Sci.70:23662373.

Grummer, R. R. (2007): Strategies to improve fertility of high yielding dairy farms: Management of the dry period. Theriogenology 68S(Suppl.1):281-288.

Grummer, R. R. and Rastani, R. R. (2004): Why Reevaluate Dry Period Length? J. Dairy Sci. 87:(E. Suppl.):E77-E85

Grummer, R. R. and Rastani, R. R. (2005): Strategies for Shortening the Dry Period. Proceedings of the $7^{\text {th }}$ Western Dairy Management Conference March 9-11, 2005 Reno, NV 129- 140

Grummer, R. R.; Bertics, S. J. and Hackbart, R. A. (2000): Effects of prepartum milking on dry matter intake, liver triglyceride, and plasma constituents. J. Dairy Sci. 83:60-61.

Gulay, M. S.; Hayen, M. J.; Bachman, K.C.; Belloso, T.; Liboni, M. and Head, H. H. (2003): Milk production and feed intake of Holstein cows given short $(30-d)$ or normal (60-d) dry periods. J. Dairy Sci. 86:2030-2038.

Gümen, A.; Rastani, R. R.; Grummer, R. R. and Wiltbank, M. C. (2005): Reduced dry periods and varying prepartum diets alter postpartum ovulation and reproductive measures. J. Dairy Sci. 88:2401-2411.

Hamann, H.; Wolf, V.; Scholz, H. and Distl, O. (2004): Relationships between lactational incidence of displaced abomasum and milk production traits in German Holstein cows. J.Vet. Med. Series A-Physiology Pathology Clinical Medicine 51:203-208.

Hooijer, G. A.; Lubbers, R. B. F.; Ducro, B. J.; van Arendonk, J. A. M.; Kaal-Lansbergen, L. M. T. E. and van der Lende, T. (2001): Genetic parameters for cystic ovarian disease in Dutch black and white dairy cattle. J Dairy Sci 84: 286-291

Kim, I.. H. and Suh, G. H. (2003): Effect of the amount of body condition loss from the dry to near calving periods on the subsequent body condition change, occurrence of postpartum diseases, metabolic parameters and reproductive performance in Holstein dairy cows Theriogenology 60:1445-1456.

Kimura, K.; Goff, J. P.; Kehrli, M. E.; Reinhatdt, T. A. (2002): Decreased neutrophil function as a cause of retained placenta in dairy cattle. J Dairy Sci. 85:544-50.

Kuhn, M. T. and Hutchison, J. L. (2005): Methodology for estimation of days dry effects. J. Dairy Sci. 88:14991508 .

Kuhn, M.T., Hutchison, J. L. and Norman, H. D. (2005): Minimum days dry to maximize milk yield in subsequent lactation. Anim. Res.54:351-367.

Kuhn, M. T., Hutchison, J. L. and Norman, H. D. (2006): Effects of dry period length on yields of milk fat and protein, fertility and milk somatic cell score in the subsequent lactation of dairy cows. J. Dairy Res. 73:154162.

Liefers, S. C.; Veerkamp, R. F.; te Pas M. F. W.; Delavaud, C.; Chilliard, Y. and van der Lende, T. (2003): Leptin concentrations in relation to energy balance, milk yield, intake, live weight, and estrus in dairy cows. J Dairy Sci 86: 799-807.

Lotan, E., and Adler, J. H. (1976): Observations on the effect of shortening the dry period on milk yield, body weight, and circulating Glucose and FFA levels in dairy cows. Tijdschr.Diergeneeskd. 101:77-82.

Lucy, M. C. (2001): Reproductive loss in high-producing dairy cattle: where will it end? J Dairy Sci 84: 1277-1293

Makuza, S. M. and McDaniel, B. T. (1996): Effects of days dry, previous days open, and current days open on milk yields of cows in Zimbabwe and North Carolin. J. Dairy. Sci. 79:702-709.

Mason, T. M. Goh, T.; Tchipashvili, V.; Sandhu, H.; Gupta, N.; Lewis, G. F. and Giacca, A. (1999): Prolonged elevation of plasma free fatty acids desensitizes the insulin secretory response to glucose in vivo in rats. Diabetes 48 , 524-530

Merk veterinary manual (1998): Eighth Ed. Merck \& Co., Inc. Whitehouse Station, NJ, USA.

NRC - National Research Council- (1989): Nutrient Requirements of Dairy Cattle, sixth revised edition. National Academy of Science, Washington, DC, USA, pp. 135-156.

NRC- National Research Council- (2001): Nutrient Requirements of Dairy Cattle, Seventh revised edition. National Academy of Science, Washington, DC, USA, pp. 258-265.

Pezeshki, A.; Mehrzad, J.; Ghorbani, G. R.; Rahmani, H. R.; Collier, R. J. and Burvenich, C. (2007): Effects of short dry periods on performance and metabolic parameters in Holstein Dairy cows. J. Dairy. Sci. 90: 5531-5541.

Pezeshki, A.; Mehrzad, J.; Ghorbani, G. R.; DeSpiegeleer, B.; Collier, R. J. and Burvenich, C. (2008): Effect of dry period Length reduction to 28 days on the performance of multiparous dairy cows in the subsequent lactation. Can. J. Anim. Sci. 88: 449-456.

Rastani, R. R.; Grummer, R. R.; Bertics, S. J.; Gümen, A.; Wilt-bank, M. C.; Mashek, D. G. and Schwab, M. C. (2005): Reducing dry period length to simplify feeding transition cows: Milk production, energy balance, and metabolic profiles. J. Dairy Sci. 88:1004-1014.

Reist, M.; Koller, A.; Busato, A.; Küpfer, U. and Blum, J. W. (2000): First ovulation and ketone body status in the early postpartum period of dairy cows. Theriogenology 54 : 685-701.

Remond, B.; Ollier, A. and Miranda, G. (1992): Milking cows in late pregnancy: milk production during this period 
and during the succeeding lactation. J. Dairy. Res. 59: 233241.

Remond, B.; Rouel, J.; Pinson, N. and Jabet, S. (1997): An attempt to omit the dry period over three consecutive lactations in dairy cows. Ann. Zootech. 46:399-408.

Ricken, M.; Hamann, H.; Scholz, H. and Distl, O. (2004): Genetic analysis of the prevalence of abomasal displacement and its relationship to milk performance in German Holstein cows Deutsche Tierarztliche Wochenschrift. 111:366-370 .

Rohn, M.; Tenhagen, B. A. and Hofmann, W. (2004): Survival of dairy cows after surgery to correct abomasal displacement: 1. Clinical and laboratory parameters and overall survival Journal of Veterinary Medicine Series APhysiology Pathology Clinical Medicine 51:294-299.

Royal, M. D.; Darwash, A. O.; Flint, A. P. E.; Webb, R.; Woolliams, J. A. and Lamming, G. E. (2000): Declining fertility in dairy cattle: Changes in traditional and endocrine parameters of fertility. Anim. Sci. 70:487-501.

Rukkwamsuk, T.; Geelen, M. J. H.; Kruip, T. A. M. and Wensing, T. (2000): Interrelation of fatty acid composition in adipose tissue, serum, and liver of dairy cows during the development of fatty liver postpartum. J Dairy Sci. 83: 5259

SAS User's Guide (1996): SAS User Guide. SAS Inst. Inc., Cary, NC.

Schaeffer, L. R. and Henderson, C. R. (1972): Effects of days dry and Days open on Holstein milk production. J. Dairy Sci.55:107-112.

Smith, M. C. A. and Wallace, J. M. (1998): Influence of early post partum ovulation on the re-establishment of pregnancy in multiparous and primiparous dairy cattle. Reprod. Fertil. Dev. 10:207-216.

Sorensen, J. T. and C. Enevoldsen (1991): Effect of dry period length on milk production in subsequent lactation. J. Dairy Sci. 74:1277- 1283.

Staples, C. R.; Thatcher, W. W. and Clark, J. H. (1990):
Relationship between ovarian activity and energy status during the early postpartum period of high producing dairy cows. J. Dairy Sci. 73:938-947.

Thatcher, W. W. and Wilcox, C. J. (1973): Postpartum estrus as an indicator of reproductive status in dairy cows. J. Dairy Sci. 56:608-610.

Thirkettle,G.L. (1985): wheldon's -Business Statistics and Statistical Methods.9th Ed.BcoM(lond) FIS.

Ulloth, J. E.; Casiano, C. A. and De Leon, M. (2003): Palmitic and stearic fatty acids induce caspasedependent and -independent cell death in nerve growth factor differentiated PC12 cells. J Neurochem 84:655-668

Watters, R. D.; Wiltbank, M. C.; Fricke, P. M.; Guenther, J. N.; Kulick, A. E. and Grummer, R. R. (2006): Effect of dry Period duration on reproductive measures during the subsequent lactationin Holstein cows.J. Dairy Sci. 89: 386.

Watters R. D.; Guenthier, J. N.; Brickner A. E.; Rastani, R. R.; Crump, P. M.; Clark, P. W.; Grummer, R. R. (2008a): Effects of Dry Period Length on Milk Production and Health of Dairy Cattle J. Dairy Sci., 91(7), 2595-2603.

Watters, R.; Fricke, P.; Wiltbank, M.; Clark, P. and Grummer, R. (2008b): Effect of dry period length on reproductive measures, health, and production of Holstein cows during the subsequent lactation.4th State Nutrition Conference-Dry Period Management. Wisconsin-MadisonUSA

Wildman, E. E.; Jones, G. M.; Wagner, P. E.; Boman, R. L.; Troutt, H. F. and Lesch, T. N. (1982): A Dairy Cow Body Condition Scoring System and Its Relationship to Selected Production Characteristics. J Dairy Sci 65:495501.

Zulu, V. C.; Sawamukai, Y.; Nakada, K.; Kida, K. and Moriyoshi, M. (2002): Relationship among Insulin-Like Growth Factor-I, blood metabolites and post partum ovarian function in dairy cows. J. Vet. Med. Sci. 64: 879-885.

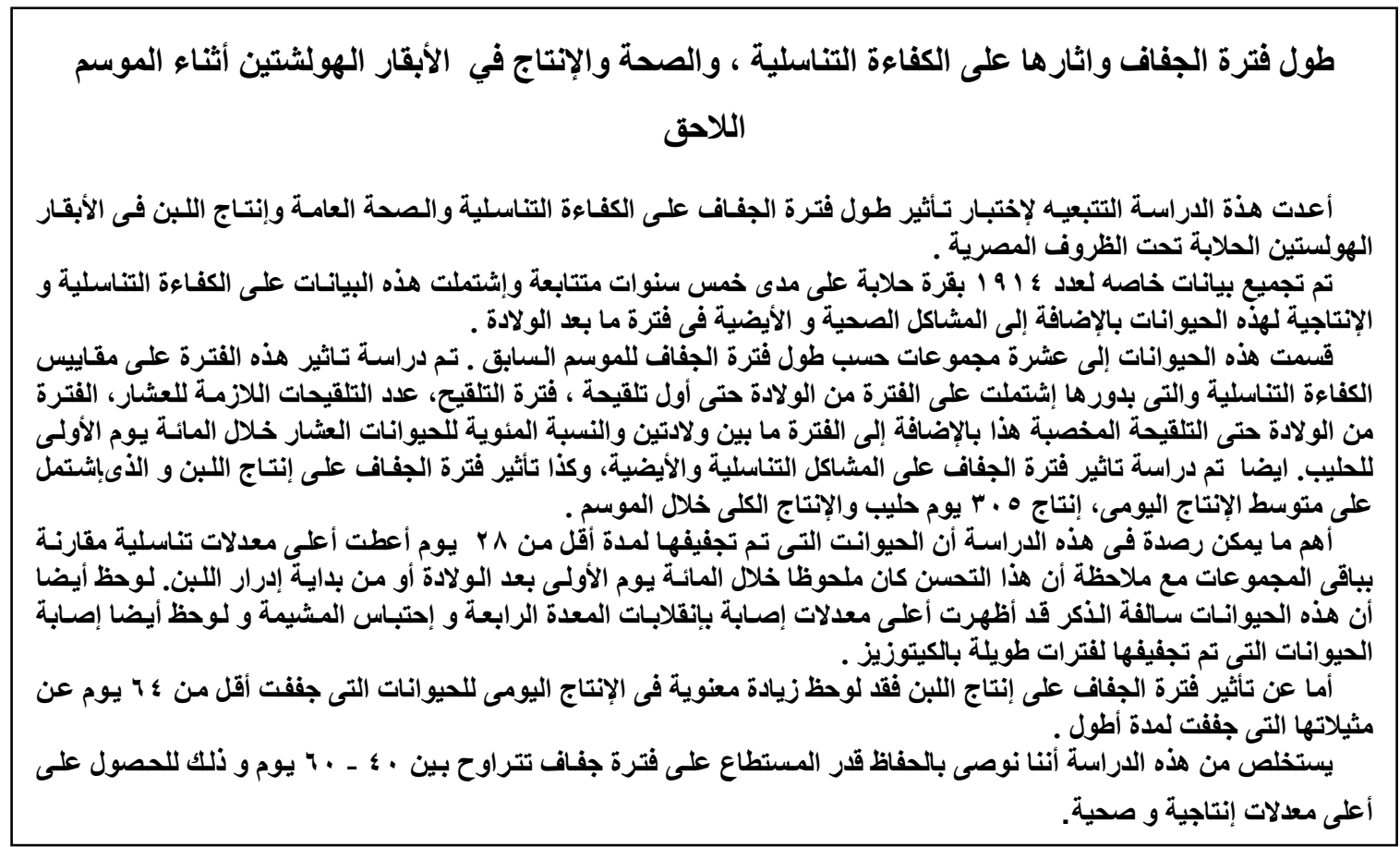

